ESJ Humanities

\title{
An Analysis of Youth Deradicalization Programs in Northeast Nigeria: A Study on Boko Haram
}

\author{
Mustapha Salihu (PhD Candidate)
}

Conflict Peace \& Strategic Studies, Nile University of Nigeria, Abuja

Doi:10.19044/esj.2021.v17n13p21

Submitted: 05 February 2021

Accepted: 23 March 2021

Published: 30 April 2021
Copyright 2021 Author(s)

Under Creative Commons BY-NC-ND

4.0 OPEN ACCESS

Cite As:

Salihu M. (2021). An Analysis of Youth Deradicalization Programs in Northeast Nigeria: A Study on Boko Haram. European Scientific Journal, ESJ, 17(13), 21.

https://doi.org/10.19044/esj.2021.v17n13p21

\section{Abstract}

Using qualitative secondary analysis, the research examine the effects of Operation Safe Corridor (OSC), a home-grown prison-based deradicalization program targeted at low-risk Boko Haram combatants, and Yellow Ribbon Initiative, an education-based recivilization program designed for young adult women associated with Boko Haram. Together with pioneer countries like Saudi Arabia and Indonesia, the structural design and implementation of OSC remain shrouded in utmost secrecy. Even though it claims to have rehabilitated over 2,000 ex-Boko Haram combatants, there is no medium to independently ascertain these claims. Relatedly, the Yellow Ribbon Initiative also claimed to have successfully reintegrated thousands of women, with little to no means to validate their claims independently. Premised on the need to implement context-specific, inclusive and robust counterinsurgency programs, the research takes issues with both programs. Furthermore, the lack of accountability and transparency in the operations of both programs put to question their credibility and objectiveness. Alternatively, the research suggests the need for a paradigm shift from deradicalization to counter-radicalization, as this will put the government on the offensive side against radicalization. If targeted at volatile communities, counter-radicalization could be designed to address underlying causalities such as unequal education opportunities and poor social infrastructure, which will in turn foster a sense of belongingness in deprived and impoverished youths in the Northeast. 
Keywords: Radicalization, Deradicalization, Prison Program, Counterradicalization, Yellow Ribbon Initiative, Boko Haram

\section{Introduction}

Conventional knowledge suggest Nigeria's predisposition to deploy security forces to counter violent outbreaks or conflict situations which has over time yielded desired outcomes. The same however cannot be said for Boko Haram. Although erstwhile leader Muhammad Yusuf and scores of his devotees were neutralized by security forces in 2009 , and all seem to be going as planned, arm carrying members surfaced sometime in 2010 under the leadership of Abubakar Shekau. The second coming of Boko Haram brought about untold hardship to the Northeast and beyond. This can be seen in killing scores of civilians, kidnapping of schoolgirls, and forceful conscription of youth into the sect, as they went on to challenge the legitimacy of secular authorities (Mosch, 2019).

From a small unknown variant of unconventional Islamic devotees who adhere to Wahabism, a radical interpretation of Islam, BH today arguably leads the pack of the arm carrying groups that threaten internal security architecture in Nigerian and neighboring Lake Chad Basin. Findings of a study by the Council on Foreign Relations (CFR), a non-profit organization, estimates the human casualties from the Boko Haram insurgency to be in the range of fifty thousand, and over two million persons have been internally displaced (Onouha, 2014). With BH seemingly gaining in strength and growing its rank, questions arise as to why young men (henceforth youths) join Boko Haram.

In the extensive literature on $\mathrm{BH}$, there seem to be a consensus amongst scholars and policymakers that poverty, unemployment, illiteracy, bad governance, and lack of development in rural communities in the region constitutes some of the main drivers of youth radicalization. Furthermore, itinerant religious preachers have exploited the fragility of social structures to propagate extreme interpretations of religious teachings and passing on a storyline that portrays secular authority as corrupt and vile. They are known to train would-be radicals in the handling of military hardware and the art of guerilla warfare. Radicalized youths are made to participate in Boko Haram's reign of terror or used as suicide bombers (Onapajo et al., 2020; Mercy Corps, 2016; Walker, 2012). Boko Haram have also made the most of harsh economic realities in the Northeast by enticing would-be combatants with offers of cash payments in exchange for their devotion to the cause (The New Humanitarian, 2015). In a study by Mercy Corps (2016), a defecting Boko Haram combatant who has been with the sect for three years claims he joined the group to save himself and his extended family from persecution and to secure funds that will enable him venture into a lifelong dream of trading. He also claims his family 
home was sparred when Boko Haram attacked his village. While another defector claimed he joined the group to enable him save up money to procure a motorcycle. He deserted the group two years after joining them; during his time with the sect, he was separated from his family and was ordered not to keep in touch with them.

While the discussion on the determinant of youth radicalization has received significant scholarly attention, inconsequential efforts have been committed to understanding what the governments and their developmental partners have done to counter this trend. Thus, the paper examines ongoing efforts of the government and OSCs to entice defectors into joining available deradicalization programs. In 2016, the Nigerian government reviewed its frameworks for countering youth deradicalization to include Operation Safe Corridor. A home-grown prison-based deradicalization program is designed for low-risk repentant Boko Haram combatants. The program combines a range of programs and initiatives, which include tolerant religious education, counseling, and technical skills while in detention. While Neem Foundation, a OSC, runs a United Nations funded initiative tagged "Yellow Ribbon", which aims to reintegrate young male and female adults who have been coerced or brainwashed into pledging their allegiance to the sect. The study assesses both programs intending to ascertain their efforts, gains, and challenges of deradicalizing former devotees, with emphasis on youths. For the purpose of this analysis, youth is defined from an age-grade perspective, herewith referring to persons between the ages of 18-35 years respectively. The decision to focus on the youth was informed by survey-based evidence across forty-seven developing countries. This mainly shows that young men between the ages of 15 and 25 are the most active in the role of offenders (UNODC, 2019).

\section{Methodology}

To examine the deradicalization of former $\mathrm{BH}$ youth in the Northeast, the study adopts a qualitative research approach by informing its reliance on secondary qualitative literature. Secondary analysis of qualitative data is obtained in the systematic review of prior data with a view of addressing research questions or propositions other than those examined in the original research. The logic of using prior data has become increasingly acceptable due to its widespread usage and recognition by researchers. Albeit its shortcomings and limitations as it concerns generalization of findings and ethical issues in research, prior data in the form of qualitative data offer narratives that examine issues similar to those in prior studies. However, it has not been examined or analyzed in a detailed fashion (Long-Sutehall et al., 2010). Materials for analysis includes journal articles, reports from an international organization, expert opinions, and publications from 
international dailies amongst other secondary sources considered relevant to the research.

Furthermore, the study attempts a conceptual framework of youth deradicalization in the context of Boko Haram. The analysis then moves to reviewing mainstream perspectives as obtained in the literature and policy documents on deradicalization. Also, it highlights how it differs from counterradicalization. The subsequent section examines and assesses the workings of the Prison Program (PP) and Yellow Ribbon (YR) initiatives. The analysis turns to look at what could be done contrary to what is presently obtainable.

\section{Youth Radicalization in the Context of Boko Haram}

Before moving on to discuss the contextual dynamics of youth radicalization as it concerns $\mathrm{BH}$, it is imperative to highlight the centrality of the National Framework for Countering Violent Extremism as prepared by the Office of the National Security Adviser (ONSA). Thus, this is the guiding principle upon which Nigeria's strategies from CVE is implemented. National Security Strategy, as it is referred to in other times, accentuates the conviction of a widely acknowledged view that security is the cornerstone of development and progress in a free society, and that security is a reflection of the social order and stability of a state. The document concludes that security transcends beyond the dominant state-centric approach, to include a robust understanding of the concept which underscores the significance of human security. Further to this, the strategy reorients state action towards current and perceived future challenges by using available resources flexibly and efficiently. It is the opinion of the ONSA that the strategy will strengthen prevention, protection, and response capabilities to security threats in an increasingly complex environment (Office of the National Security Adviser, 2019).

Central to the rising influence of terror groups all over the world is the relative ease at which such groups are able to radicalize and conscript the youth to join them on their wars against constituted authorities. However, conscription is only the beginning, and radicalization seemingly remains more complex to demystify. Radicalization, as obtained, has generated widespread concern in terms of how to deal with its twin component, i.e., violence. It is evident that the violent aspect of radicalization has greatly decimated populations, maimed innocent citizens, and destroyed unquantifiable properties, thereby retarding the socio-economic and political development of many nations. Pathetically, the gladiators in the blood-stained theatre of violent religious groups like Boko Haram are mainly radicalized young people (Naboth et al., 2015).

Like numerous other concepts in social science, radicalization continues to elude meaningful attempts targeted at affording a universal 
interpretation or even indicators for measurement. The research adopts the definition of radicalism which understands it to mean something proceeding from a root or origin marked by significant parting from the conventional ideas, values, and social norms, which tend to introduce extreme and consequential alterations in the existing doctrines, conditions, or institutions (Onapajo et al., 2020 and Naboth et al., 2015). Similarly, it is argued that radicalization starts ideally with changes in one's self-identification concerning a group or ideology. Grievances, frequently driven by personal or group concerns regarding local issues as well as international events, fuel this type of collective action approach to pursuing ends (Alex et al., 2010).

It will suffice to argue that individuals who abhor extreme and uncompromising views on existing ideals fit the description of a radical, who turn out to be against constituted authorities or the social order of a society. Radicals are known to be advocates of extreme structural overhaul which could either be negative or positive depending on the level of radicalization such individuals have been exposed to. As it concerns $\mathrm{BH}$, radicalization is understood to mean an intricate and complex process through which factors result from non-tolerant and extremist interpretations of Islam. Their moral world view differs significantly from the more tolerant and accommodating Sunni Islamic ideals. Hence, the BH ideology is located within the doctrines of religious extremism. In other words, beyond economic incentives, the group relies significantly on brainwashing prospective radicals to sympathize with their extremist views on Islam. Thus, devotees are indoctrinated through rigorous brainwashing which in turn leads to rad.

According to Prus (2018), extreme religious behaviors seek to promote unpopular sets of activities based on individual or group world view on morality tied to a peculiar belief systems. Furthermore, he contends that other forms of religious extremism include monastic seclusion of members, the extended proselytization of non-members, the vilification of outsiders as well as sinners within, the criminalization of non-compliant persons, and the eradication of designated enemies. For Beit (2017), religious extremism tends to antagonize the core of secularization and other religious groups who do not share in their instrumentality of violence as a religious obligation. At this juncture, it is imperative to highlight that while $\mathrm{BH}$ feeds predominantly on religious susceptibility to conscript members, there is no single path to radicalization. It could happen in schools, neighborhoods, and it could also be targeted at individual youths or towards communities. Therefore, this study contends against this as becoming an extremist cannot be a flash of the moment's decision. It could be that radicalizing youth may have given the extremist ideology a considerable thought and time; a period by which sufficient indoctrination may have taken place and indeed a time by which the young radicals are prepared to step into the phase of radicalization process and 
consequently violent extremism. Before the thought and decision of radicalizing, there are likely reasons for toeing the path of extreme violence. Radicalization and the logic behind it have informed studies into what has been described as theories or models of radicalization. Borum (2014), Silker et al. (2007), and Pretcht (2007) agreed on the existence of four main stages which transforms radicalization into violent extremism. Borum (2014) propose a four-stage model of terrorist outlook which rests on grievances against perceived or actual injustice attributed to persons, ideology, or institutions. In the context of $\mathrm{BH}$, the study argues that the controversial circumstances surrounding the death of their erstwhile leader, Muhammad Yusuf, in police custody arguably sparked a mutual sense of injustice amongst his followers. This is in addition to the killing of hundreds of its members sometime in 2009 (Onouha, 2015). This alongside with other causalities arguably triggered a sequence of events that fed the waves of the anger of its members, driving them into seclusion. The timeframe between military aggression and their resurgence in 2010 was the withdrawal stage, while their resurgence marks the demonization and violence stage where the sect members set out to redress the injustice meted on them by the Nigerian state adopting indoctrination and brainwash of the young population as a means to their ends. The relative silence from the sect between the death of their leader and their resort to violence was obtained in Borum's second phase. Borum's process is characterized by manifested grievances against injustice, which informed withdrawal and their ulterior motives of deploying violence as a means to their ends.

Borum's model seemingly shares some attributes with Van San et al. (2013) on theory of Opponents versus Enemies. It is aptly expressed in what Mouffe (2005) calls a "we/they discrimination" which is not defined in political terms, but rather in moral terms. With recourse to $\mathrm{BH}$, their seeming lack of interests in material benefits or political stake, and continued reference to secular authorities as vile and corrupt, is aptly captured in the arguments of the theory of Opponent versus Enemies as obtained in Van San et al. (2013). For Silber et al. (2007), their four-stage model of Jihadization consists of preradicalization, self-identification, indoctrination, and Jihadization. There is no much difference between Silber and Bhatt (2007) and Pretcht's (2007) typical radicalization pattern. Therefore, the four stages are as follows: preradicalization, conversion and identification with radical Islam, indoctrination and increased group bonding, and actual acts of terrorism of planned plots.

As earlier stated, there exists no standard or procedural approach to radicalization. In the case of $\mathrm{BH}$, evidence abounds to suggest that the sect deploys several strategies which can be broadly grouped under coercion and indoctrination as the key avenues employed by the sect. The existential reality of high poverty rates, soaring numbers of out-of-school children, widespread 
violence and youth restiveness, and also predisposition to carrying out religious obligations judiciously seems to also play a role in driving the radicalization of poorly educated youths in the Northeast. BH ransacks rural communities and kidnaps youth, men and women, who are coerced into service, while the girls are married off to their devotees or sold off at ridiculous amounts. These youths are then hardened through ideology and trauma.

If they try to leave, they are told their family members will be tortured and killed. Once affiliated with the sect, their former communities are loath to take them back fearing that they have been lost to the insurgents and their way of thinking is unlikely to remain same after their encounter with the group. Also, their former communities hardly see them as victims. While the vast majority of $\mathrm{BH}$ fighters come from the illiterate poor, usually the Hausa or Kanuri tribes, some are more educated and are radicalized through extremist ideology. Traditional Muslim mullahs and religious leaders denounce Boko Haram but often pay for that with their lives (Thompson, 2016; Blair, 2015).

Arguments also abound to suggest that some youth associated with $\mathrm{BH}$ live in communities where they act as spies and provide information to the sect. Findings of the research, which interviewed young suspected $\mathrm{BH}$ members who were released by the military, claimed BH paid them 5,000 naira each (about \$12 U.S. dollars at N470 to \$1) to set schools in Yobe and Borno states on fire and spy on soldiers. According to one of them, "we watched out for the soldiers at their units and reported back to them. We were reporting when soldiers were at ease or when they were off guard and we were paid for doing that" (Alechenu, 2013).

Against this, the views of this study that BH develops, through a wellplanned program, their capacity and audacity to ransack villages and kidnap young boys and girls speaks volume of their dare-devil attributes. Over time, the militant group has diversified its funding sources from foreign terrorist groups, bank robberies, cattle rustling, drug trafficking, extortion, engagement in 'front' businesses, collection of levies, and kidnapping for ransom. According to Oyewole et al. (2017), BH has made over US\$10 million from kidnapping for ransom, considering US $\$ 3.75$ million was allegedly paid by the Cameroonian government between 2013 and 2014, and $€ 7$ million by the government of Nigeria between 2017 and 2018. It is thought that BH as an organization has as well over 6000 active combatants with a transnational reach (Onapajo et al., 2020; Rufai, 2017).

\section{Counter-Radicalization and Deradicalization: Frameworks for Analysis}

For a successful counter-terrorism campaign, scholars and policymakers underlie the significance of deploying a combination of military and non-military strategies. While military strategy is required to counter the military capabilities of armed groups like $\mathrm{BH}$, evidence abound to suggest the 
inadequacies of military operations to counter insurgents and informed a review of Nigeria's response to the BH insurgency (Onapajo et al., 2020). Although evidence abounds to suggest Nigeria's growing predisposition to deploy non-military strategies, these programs or initiative are predominantly reactive in nature. The implication of this is that the government continues to rely significantly on the military to dislodge the sect members, after which deradicalization programs like Nigeria's home-grown prison deradicalization program are deployed to entice defectors. Given the unconventional and protracted nature of the insurgency, the study suggests the need to review nonmilitary efforts like deradicalization. Alternatively, the research examines the viability of counter-radicalization as a strategy for Countering Violent Extremism (CVE).

\section{Counter-Radicalization}

If we agree that decision by individuals to take up arms against the state for any cause is not a spontaneous one, then we can also agree that recruitment is an intricate process that derives from the exploitation of grievances and preys on the personal vulnerabilities of individuals as a tool for conscription. Against this background, the research suggests that non-punitive strategies for CVE should emphasize de-appealing the factors that inform recruitment and conscription. Thus, counter-deradicalization is herewith understood and examined as preventive strategies as opposed to reactive strategy obtained in deradicalization.

Counter-radicalization efforts are understood as the strategies that are designed towards thwarting radicalization from happening and to cut off those persons who are in the process of radicalizing. These efforts are closely associated with counter-polarization efforts which opt to drive healthy pluralism and reduce divisions between different groups in society (European Policy Plan Network, 2015). Put differently, counter-radicalization emphasizes the promotion of formidable communal values which aims to make communities resilient to harmful and violent influences. A major distinction between counter-radicalization and deradicalization abounds in their timing, unit of analysis, and target audience. Counter-radicalization is ideally targeted at communities, while deradicalization is targeted at reversing individual violent ideologies.

As a concept, counter-radicalization may have best been verbalized by the Former Foreign Minister from Norway, Jonas Gahr Storer, when he wrote in the New York Times that extremism, whether political, religious or otherwise, does not grow in emptiness. Ideas are the oxygen that allows them to flourish and spread. Extremist perspectives win sympathy and recruit because they offer narratives that claim to identify deep injustices and enemies. Without this fuel, the blaze of extremism is quickly extinguished 
(New York Times, 2012). Hoeft (2012) stated that the basis of counterradicalization is obtained from a line of thought that claims along the path of radicalization. Thus, the individual will continually assess and interpret their environment through pragmatic, emotional, and/or spiritual lenses before arriving at a point where they either commit themselves to active extremism or stray from the path. Counter-radicalization, therefore, aims to interrupt the process of radicalization by offering prospective extremist alternative worldviews.

They also seek to destabilize the individual's resolve to radicalize through counter-narratives, refutations, education, and positive examples. It also attempts to encourage individuals to channel their passion in ways deemed more societally acceptable. In the case of youths, counterradicalization efforts may lead to a systematic redeployment or removal of such individuals from toxic environments to reduce the prospects of susceptibility (Asim, 2015). For Basia (2012), counter-radicalization efforts do not necessarily embody or reflect obvious counter-terrorism nature. Initiatives like taking down the online presence of groups with radical worldviews could limit their ability to propagate hateful and intolerant ideas. Publishing and promoting counter-radical narratives, monitoring, tracking, and engaging persons of interest are all community-based radicalization prevention initiatives.

Sometime in February 2021, the Kano state government obtained a court order to enable it shut down worship centers linked to controversial Islamic preacher and cleric Sheik Abdul-Jabbar Nasir Kabara. The court order admonished security outfits to be conscious and act swiftly in taking appropriate measures against anyone who indulges in disseminating or preaching divisive sermons that endanger public peace and communal tolerance (Desmond, 2021). Although the preacher cited political difference as the motive behind the court order, void of ulterior motives, such steps can be designed to counter or interrupt radicalization at communal level. Secondly, the vocational empowerment of youths in a rural community may also address the domino effects of poverty and restiveness on radicalization. Furthermore, communication between state and volatile communities, as well as the incorporation of tolerant religious institutions, schools, recreational associations, parents, and mentors can also be deployed as resources to counter radical narratives. To this end, the emphasis on counter-radicalization moves to validate the views that suggest radicalization itself is dangerous and suppresses the propagation of radical narratives at the societal level (Tom, 2017). 


\section{Deradicalization}

Mainstream scholars on deradicalization (Bjorgo, 2009; Feddes, 2015) tend to create a conceptual differentiation between disengagement and deradicalization in which disengagement is understood to mean a behavioral change. In disengagement, the individual desists from or reduces their use of violence. On the other hand, deradicalization aims at both behavioral and cognitive change. On this basis, the research argues that deradicalization and disengagement describe processes whereby individuals or groups discontinue their participation in organized violence and/or terrorism. While deradicalization aims for fundamental changes in ideology and attitudes, disengagement focuses on enabling behavioral alteration in the context of the denunciation of violence. According to John (2019), disengaged terrorists may not be deradicalized or repentant at all. Oftentimes, physical disengagement may not result in any concomitant change or reduction in ideological support (Omar, 2009).

Prior research suggests that identity remains one of the principal preconditions for radicalization, in the sense that collective action will be unlikely in the absence of a cogent sense of collective identity or mutual feeling of belongingness (Huddy, 2001). Further to which when a group of individuals are collectively spurred into action, it becomes difficult to switch it off (Van Stekelenburg et al., 2007). Other scholars examine the role of critical incidents or turning points such as traumatic events, which provide the devotees with necessary self-awareness and drives individuals to consider deradicalization (Altier et al., 2014). Amongst other factors, the research suggests that identity change could be attained through re-orientation, counseling, migration, and even or equal education opportunities.

However, current efforts to countering religious terrorist groups like $\mathrm{BH}$ remain particularly militarized, which is targeted at weakening support systems, intercepting supplies, and thwarting terror plots using available intelligence (White House, 2015). Ideally, captured or defecting members of terrorist groups are often not incarcerated in detention centers (Fischer \& Graves, 2011). In this regard, detainees awaiting trial or judgment become a captive audience for deradicalization efforts designed to disabuse them of the violence justifying ideology to which they subscribe, dissuade them from active engagement in violence, and reintegrate them into the society (Webber et al., 2017). Evidence also abounds to suggest that prison or the experience of incarceration has also been shown to be important to the deradicalization processes (Sukabdi, 2015). At the most basic level, incarceration plays a role in at least temporarily forcing the militant to disengage in the violence by taking them off the hostilities and survival contests on the battlefield. In the same vein, it can also provide the militants with the space to consider their ideology, reflect on the conflict, and develop longer-term strategies which can 
include non-violent approaches to achieving their political goals (Ashour, 2011).

In Nigeria, the pursuit of a practical way to evocatively address religious terrorism has led to the oscillation of different counterinsurgency strategies (military, political, and developmental approaches), all of which have fallen short of attaining predetermined objectives (Uzodike et al., 2015). Given that non-military approaches including amnesty, political co-optation, and empowerment programs previously advanced by the government failed to achieve desired results, there was more focus on military engagements to fight the terrorists. The recognition that the war model has not only failed to reduce violence but also increased the number of deaths in the conflict zones (and attracted mounting criticisms) may have motivated the state to reconsider the usefulness of non-military strategies, especially a deradicalization strategy (Onapajo et al., 2020). Approximated figures suggest that there are around 500,000 individuals in a variety of arm-carrying non-state militias scheduled to undergo various forms of Demobilization, Deradicalization, and Rehabilitation (DDR) programs across Africa (Prosper, 2013).

Nigeria's attempts to broaden its counterinsurgency framework to accommodate deradicalization programs obtain in the deployment of the home-grown Operation Safe Corridor (OSC), a prison-based deradicalization program. The program seeks to provide defecting or captured $\mathrm{BH}$ devotees a pathway to deradicalization. Despite the growing trend of incarceration-based deradicalization, Nigeria's PP has met with stiff opposition across different quarters. Not only is the viability of the program questioned, it has been labeled insensitive by critics. Attempts to re-civilize ex-combatants can be seen as a misplaced priority due to the relatively slow pace at which the government is resettling persons displaced by the insurgency or even alleviate living conditions in displacement camps (Campbell, 2019). While the PP focuses on ex-combatants, the Yellow Ribbon (YR) initiative by Neem Foundation, a civil society organization, focuses on educating young female adults that were once captives and or devotees of $\mathrm{BH}$, as a means to deradicalize and re-civilize them. As earlier stated, the study examines both programs in a bid to ascertain their impact on youth deradicalization in the Northeast.

On this account, it is pertinent to underscore the difficulties obtained in measuring the efficiency of deradicalization in the absence of direct observation, monitoring, and evaluation of defecting BH devotees. In addition, the study depends on the submissions of deradicalization theorists to arrive at its conclusion. Based on what follows, the PP and YR initiatives are examined based on existing frameworks and models for examining deradicalization. 


\section{The Prison Program}

Although conventional knowledge suggests prisons are hotbeds of radicalization and suitable for building terror networks and plots, a body of research examine the challenges and opportunities of countering insurgency within the prison walls. Prior literature addresses a vast array of issues, such as the risks of radicalization in prison (Nathan, 2017), as well as cost-benefit assessment and classification, management strategies, and rehabilitation and reintegration approaches (Crawford, 1999).

In a little over one decade, the number of states that have adopted imprisonment as a strategy for Converting Violent Extremists through the popular framework "Countering Violent Extremism" (CVE), particularly the radical Islamist, has grown significantly. Too often, these programs claim to have successful re-civilized ex-combatants and had boosted startlingly low rates of recidivism among re-civilized ex-militants. The government of Saudi Arabia, for instance, claim that its deradicalization program has succeeded in rehabilitating 80 percent of the militants targeted, and that less than 5 percent of their detainees have been rearrested (Angel et al., 2013). Similarly, as of June 2008, the U.S.-run Iraqi deradicalization program claims that out of the 10,000 prisoners released, only 33 committed further offenses. Although Singapore's deradicalization program is much smaller than the Saudi or Iraqi program, Singapore's government maintains that only one of the 40 former radical Islamists who have been freed has been detained again (Marisa, 2010). Taken at face value, these data suggest that prison-based programs aiming to reform militant Islamists are extremely successful and that other states should employ similar methods to combat radicals. However, these assertions need to be further scrutinized before it is possible to reach any conclusion about the efficacy of imprisonment as a viable hub for deradicalization of captured or defecting extremists (Angel et al., 2010).

Despite seeming opposition, deradicalization programs are not only encouraged, as a non-punitive counterinsurgency strategy, but its acceptance also highlights the limits of military repression in Countering Violent Extremism (CVE). As a result, many nations have developed programs that address both counter-radicalization and deradicalization. The program which aims to deradicalize defecting low-risk repentant $\mathrm{BH}$ fighters and reintegrate them back into society includes religious deradicalization programs, vocational training, counseling sessions, and civic programs that increase their chances of being productive upon release from the program. Since Operation Safe Corridor's (OSC) commencement in May 2016, many have expressed strong reservations and disapproval against the program (Center for Democracy and Development, 2017).

The National Security Strategy made it clear that the Countering Violent Extremism program should involve the design of a prison-based 
deradicalization program for prisoners under the Terrorism Prevention Act and for suspects awaiting trial, as well as an after-care component for those who might be released by courts or in the event of a government decision arising from on-going dialogue (The National Counter-Terrorism Strategy, 2014). Although Nigeria's effort should be commended, however a lot of questions with regards to prison-based deradicalization initiatives remain largely unanswered in the mainstream literature and policy papers. Among others, some of the unanswered questions as observed across numerous prior studies include; how does one measure the efficiency of a deradicalization program? Should a program be judged by the proportion of prisoners who desist from reengaging with violent groups upon their release? Is there a standard framework for deradicalizing case-specific extremist, religious, and political ideologies? What are the merits and demerits of measurement techniques and the practical implementation of prison-based deradicalization programs (Attah et al., 2017; CDD, 2017; Angel et al., 2010)?

While it remains difficult to satisfactorily address skepticisms surrounding prison-based deradicalization, given their relative newness in CVE, countries like Saudi Arabia, Indonesia, and others are quick to adjudge their prison programs successfully, as earlier noted in the course of this discussion. Also, the Office of National Security Adviser justifies the receipt of unregulated fiscal allocation in millions of dollars for the program based on its efficacy, with little room to independently ascertain these claims. The research argues that evidence from Nigeria suggests prison-based and another non-punitive counterinsurgency approach has been successful in bringing about momentary peace. This is on the basis that resources are given to key actors, and its chances of enabling long term peace agreements are slim. More so with the $\mathrm{BH}$, the sect is only not interested in negotiations, its moral worldviews suggest that anyone who does not align with their ideologies is an outright enemy. Further to this, Nigerians are arguably hostile to the $\mathrm{BH}$ prison-program, perhaps more problematic. Many communities, after enduring years of mayhems, remain cynical of reuniting with repentant $\mathrm{BH}$ defectors. On a general note, there is also confusion about whether any kind of rehabilitation is undertaken by the deradicalization program. Measuring success has only proved to be difficult and in the interest of accessing unregulated funds, the Office of National Security Adviser is likely to sing praises of the PP, even where the realities state otherwise.

\section{Yellow Ribbon Initiative}

Tackling violent extremism (VE) as a part of educational interventions is reflective of a broader international shift towards the prevention of terrorism, and towards efforts to address the environment conducive for extremists to spread their ideologies and recruit supporters. Education has 
been leveraged to radicalize and deradicalize young people; increasingly, governments in conflict-affected countries are interested in financing measures that counter violent extremism as part of education programs (Sas et al., 2020). In recognition of causal role of illiteracy in fostering radicalization in the Northeast, Neem Foundation, a Civil Society Organization, which operates in the Northeast, runs the Yellow Ribbon Initiative (YRI). The YRI is an education-based empowerment program that focuses on deradicalizing and empowering formers/captured young female adults and children who were once associated with $\mathrm{BH}$. Although there exists very little information to counter the success stories, given the relative newness of the YRI, the study makes up for these by reviewing prior studies which examine the relations between education and deradicalization.

To begin with, the study examines the educational level of high-profile religious extremists who have attained Rockstar status. For instance, Osama Bin Laden, the founder of Al-Qaeda, graduated as an engineer, and his successor, Ayman Al-Zawahiri, completed a master's degree in surgery. Abu Bakr Al-Baghdadi, the leader of ISIS, had a PhD degree in Islamic theology (Zahid, 2017). The British sociologists Gambetta et al. (2009) confirmed these findings and concluded in their research that 196 out of 284 examined convicted international terrorists have received higher education, which is a high number in comparison with the average level of education in their countries of origin. The World Bank concluded in a report about Daesh (breakaway faction of ISIS) recruitment that the average number of years of education of the recruits exceeds the regional average of their region of origin (Mark, 1999). In Sub-Saharan Africa, there is a difference of five years of education, while in North Africa and the Middle East, a difference of three years can be observed (Rose, 2017). In other studies, a combination of welleducated and less educated participants of violent extremist groups was found. For example, Oyefusi (2011) indicated in his study about rebel groups in the Niger Delta that, oftentimes, a combination is made between a large number of less-educated youths who consider participation as an upgrade in social status and economic opportunities and a smaller group of well-educated individuals who are mainly motivated by political or ideological aspects (Oyefusi, 2011).

If the literature suggests the lack of viable correlation between underlying variables, why then is education considered as a viable alternative for deradicalization? Moser et al. (2015) argued the existence of a relationship between violence and unequal access to education, employment, health, or basic physical infrastructure. Situations where severe inequality is widespread heighten the potential for frustrated and excluded populations which may lead to an increased number of young individuals participating in different forms of violence. Breidlid (2016) suggests deep-rooted grievances about the 
unequal access to educational systems in Sudan are said to be one of the reasons for the ongoing civil war. In Sierra Leone, the failure of the government to provide qualitative and equal distribution of education for young individuals led many of them to join rebel groups (Hikler, 2009). The issue of unequal access to education seems not to be only relevant for primary and secondary education as, too often, discrimination sneaks into the admission processes for universities. Evidence abounds to suggest that Northeast Nigeria has the highest out-of-school youths, a figure which has since skyrocketed in the wake of heightened $\mathrm{BH}$ attacks in the region.

On the other divide of the argument, Shafiq et al. (2010) argued that the relationship between the educational level of a country and the risk of conflict is not straightforward. Political and socioeconomic variables may have a mediating role in this connection. This means that poor political and socioeconomic conditions may increase the chance of terrorist acts, while in favorable conditions, education may further reduce terrorism. Brockhoff et al. (2014) concluded based on an examination of 133 countries for over 23 years, which lower educational levels. For example, primary education led to more terrorism for a cluster of less socioeconomic and politico-institutional developing countries. Higher levels of education, such as university education, reduce domestic terrorism for a cluster of countries with more favorable conditions. Referring to the well-educated profiles of individuals who participated in recent terrorist attacks, previous research has shown that equal access to education does not per se minimize the risk of radicalization.

While there exists a gap in the literature on education as a strategy for CVE, with emphasis on deradicalization, this study argues that the motive behind YRI amongst others is to bridge the inequality gap in education as demonstrated in the studies examined. This could be done to reorient the mindsets and behaviors of young female adults who have suffered unquantifiable abuses during captivity or enlistment. The role of education in increasing employability, which remains a viable criterion for re-civilization of the victims, cannot be dismissed in its totality. In Nigerian parlance, however, education does not necessarily translate to job placements. Nonetheless, the study argues that YRI should be adopted or key into as part of deradicalization beyond the impact of knowledge, and being in a learning environment has the potency to foster a sense of belongingness which many of the young women and men associated with BH lacks. Society abhors these groups, and by providing an enabling environment for learning, it will suffice to argue that Neem Foundation contributes in no little measure to the recivilization prospects of the said young women. At this juncture, we suggest that the PP and YRI should make available their reports and success stories, which will serve as the basis for conducting further research on the success of non-punitive strategies in countering violent extremism. 


\section{Conclusion and Recommendation}

Given the central role of the military in the administration of Nigeria's $\mathrm{PP}$, it is imperative that officers associated with the program are qualified to handle such programs, given their lack of experience to handle such programs. While many will argue the atrocities of the sect are evident in the over 2 million internally displaced persons and the loss of tens of thousands of lives, the very idea behind deradicalization and other non-punitive strategies is disassociation from violent practices. The officials will less likely gain the trust of former devotees who are subjects to violent interrogation methods. According to this, individualization is almost non-existent in prison programs and offenders are lumped up in groups. Also with little to no requisite expertise, prison officials are less equipped to implement deradicalization programs. Although the extent to which professionals have been incorporated into the Prison Program remains unclear, conventional knowledge suggests that deradicalization is a conscious process of altering the worldview of an individual or group and as such requires the expertise of professionals. The review of prior studies shows that deradicalization is only the first step in the sequence of programs and activities put together to facilitate re-civilization. Another major aspect of the prison program which does not provide established framework is the issue of monitoring and evaluating deradicalized ex-combatants, in the absence of which such individuals may pose threat to their communities if they retain radical elements of their past. Although given the clandestine nature of the program, it will be difficult to ascertain if such mechanisms are put in place.

However, it is still very early days in the program and it will be important to monitor whether prisoners' initial level stance of defecting is maintained after re-civilization, which could serve as the basis for evaluation and assessment. Nonetheless, it is imperative that receiving communities, where ex-combatants are to be civilized, are carried along as stakeholders. This will not only foster inclusion, but it will give room for alternative opinions and also allows for feedback which is an essential component of monitoring and evaluation.

Lastly, in line to proffer alternative deradicalization strategy, the research makes a case for a reorientation of government approach on the need to deploy resources and expertise towards countering radicalization at the communal level. This could include addressing underlying drivers of deradicalization like poverty, illiteracy, socio-economic neglect, and lack of basic human and social amenities. Furthermore, efforts should be made to counter radical preaching both in religious institutions and online, while putting in place frameworks for national reorientation of the populace on the perils of deradicalization. The adoption of these measures should not replace 
ongoing efforts but should be designed to complement them, given the multidimensional channels for radicalization.

\section{References:}

1. Alechenu, J. (2013). Boko Haram Paid Us N5, 000 Each to Burn Schools-Kid Suspects, Punch, p. 3.

2. Altier, M.B., Thoroughgood, C.N., \& Horgan, J.G. (2014). Turning away from Terrorism: Lessons from psychology, sociology, and criminology. Journal of Peace Research, 51, 647-661.

3. Ashour, O. (2009). The Deradicalization of Jihadists. London: Routledge

4. Ashour, O. (2011b). Post-Jihadism: Libya and the global transformations of armed Islamic movements. Terrorism and Political Violence, 23, 377-397

5. Attah, B., \& Shayne, B. (2017). De-Radicalising Prisoners in Nigeria: Developing a basic prison-based de-radicalization program, Journal of Deradicalization, 7: 1-25

6. Asim, Q. (2015). Taking Away Your Children: Counter-Terrorism Bill 2014. Washington D. C: United States Congress

7. Basia, S. (2012). Counter-Terrorism: Community Based Approaches to Prevent Terror Crime. London: Palgrave Macmillan.

8. BBC News (2015). Nigeria Boko Haram: Militants 'technically defeated' - Buhari, December 9. 24, Available at: https://www.bbc.com/news/world-africa-35173618

9. Bjorgo, T. (2005). Root Causes of Terrorism: Myths, Reality and Way Forward. London and New York: Routledge

10. Blair, D. (2015). Boko Haram is now a Mini-Islamic State, with its own territory, Telegraph

http://www.telegraph.co.uk/news/worldnews/africaandindianocean/ni geria/11337722/Boko-Haram-is-now-a-mini-Islamic-Statewith-itsown-territory.html

11. Borum, B. (2011). Radicalising into Violent Extremism II: A Review of Conceptual Models and Empirical Research, 4(4), 37-61

12. Breidlid, A. (2017). Sudanese migrants in the Khartoum area: Fighting for educational space. Int. J. Educ. Dev., 25, 253-268.

13. Campbell, J. (2020) Mass Defection of BH Members in Cameroon. Council on Foreign Relations, August 12. Available at: https://www.cfr.org/blog/mass-defection-boko-haram-fighterscameroon

14. Centre for Democracy and Development (2017). Stakeholders Dialogue on Government Approaches for Managing Defecting Violent Extremist, Policy Brief, 
https://cddwestafrica.org/wpcontent/uploads/2017/12/StakeholdersDi alogueonGovernmentApproachestoManagingDefectingViolentExtre mists.pdf

15. Desmond, M. (2021). Ganduje Shut Popular Islamic Scholar's Mosques, Seminaries in Kano. Sunnews Online, February 6. www.sunnewsonline.com/ganduje-shuts-popular-islamic-scholar

16. Gambetta, D., \& Hertog, S. (2009) Why are there so many Engineers among Islamic Radicals? Eur. J. Sociol. Arch. Eur. De Sociol., 50, 201-230

17. Hilker, L.M. \& Fraser, E. (2009). Youth exclusion, violence, conflict, and fragile states. Soc. Dev. Direct, 30, 1-50

18. Hoeft, G. (2015). Soft Approaches to Counter-Terrorism: An Exploration of the Benefits of Deradicalization Programs, international Institute for Counter-Terrorism. www.ict.org

19. Horgan, J. (2009). Individual disengagement: a psychological analysis' in Tore Bjørgo and John Horgan (eds.), Leaving Terrorism Behind (London and New York: Routledge 2009), p. 27

20. Huddy, L. (2001). From social to political identity: A critical examination of social identity theory. Political Psychology, 22(1), 127-165

21. Mak, A. (1999). Assessing Aid: What Works, What Doesn't, and Why (A World Bank Policy Research Report). J. Dev. Stud. 35, 162

22. Jonas, G. S. (2012). Learning from Norway's Tragedy. New York Times, July 19, 2012

23. Jonathan, P. (2017). Approaches to Anti-Radicalization and Community Policing in the

24. Transatlantic Space. Hudson Institute Working Paper No.7

25. Mercy Corps (2016). Reports Investigates how Boko Haram Recruit Youths. Mercy Corps Reports, April, 8. Available at: https://www.mercycorps.org/blog/report-nigeria-boko-haram

26. Moffe, C. (2005). On the Political. London: Routledge

27. Moser, C., \& Rodgers, D. (2015). Change, Violence, and Insecurity in Non-Conflict Situations. Overseas Development Institute: London, $\mathrm{UK}$

28. Naboth, H.A., \& Godpower, A.I. (2015). Implication of Radicalisation for Nigerian Education: A Philosophical Analysis. Journal of Education and Practice. 6(21), 201-2015. Available at: https://files.eric.ed.gov/fulltext/EJ1079143.pdf

29. Onouha, F.C. (2014). Why Do Youth Join Boko Haram? United States Institute for Peace, Special Report. Available at: https://www.files.ethz.ch/isn/180882/SR348-

Why_do_Youth_Join_Boko_Haram.pdf 
30. Oyefusi, A. (2008). Oil and the probability of rebel participation among youths in the Niger Delta of Nigeria. J. Peace Res. 45, 539-555

31. Oyewole, S., \& Onuoha, F. (2018) Boko Haram's Abduction of Dapchi Schoolgirls: Context, Controversy, and Concerns, African Security Review (forthcoming)

32. Porges, M.L. (2010). Deradicalisation, the Yemeni Way. Survival, $52(2), 28$

33. Pretcht, T. (2007). Homegrown Terrorism and Islamist Radicalisation. Danish Ministry of Defence. http://tinyuril.com/ygmyfpy.

34. Prus, D. (2018). Terrorism and Religious Fundamentalism Prospects for a Predictive Paradigm. Marburg Journal of Religion, 11(1), 233241

35. Rose, M. (2017). Universities and 'radicalisation' in the Middle East and North Africa. J. Secur. Stud. 19, 49-66

36. Shafiq, N.M. \& Sinno, A.H. (2010). Education, income, and support for suicide bombings: Evidence from six Muslim countries. J. Confl. Resolut. 54, 146-178

37. Silber, M. \& Bhatt, A. (2007). Radicalisation in the West: Homegrown Threat. New York: Police Department, NYPD Intelligence Division

38. Sukabdi, Z.A. (2015). Terrorism in Indonesia: A review on rehabilitation and deradicalization. Journal of Terrorism Research, 6, $36-56$

39. Thomas, M. (2019). Opinion: Boko Haram-no end in sight. Available at: https://www.dw.com/en/opinion-boko-haram-no-end-in-sight/a49834087

40. Tom, P. (2017). De-radicalization and Counter-radicalization: Valuable Tools Combating

41. Violent Extremism, or Harmful Methods of Subjugation? Deradicalization, Nr. 12. 1-59

42. Thurston, A. (2016) The Brookings Project on U.S. Relations with the Islamic World, 'The Disease is Unbelief': Boko Haram's Religious and Political Worldview available at https://www.brookings.edu/wp content/uploads/2016/01/iwr_20160114_boko_haram.pdf

43. United Nations Development Programme (2019). Human Development Report. United Nations: New York, NY, USA, 2019

44. Uzodike, H. \& H. Onapajo. (2015). The rage of insurgency: Why Boko Haram may remain untamed. African Renaissance 12 (2), 49-70

45. Van San, M., Sieckelinck, S., \& de Winter, M. (2013). Ideals Adrift: An Educational Approach to Radicalisation. In Ethics and Education, 8(3), 276-289

46. Van Stekelenburg, J. \& Klandermans, B. (2007). Individuals in movements: A social psychology of contention. In C. M. Roggeband 
and B. Klandermans (Eds.), The Handbook of Social Movements across Disciplines (p. 157-204). New York: Springer

47. Walker, A. (2012). What Is Boko Haram? Special Report no. 308, United State Institute of Peace, Washington, DC (June 2012), 2

48. Wilner, A.S., \& Dubouloz, C.J. (2010). Homegrown Terrorism and Transformative Learning: An Interdisciplinary Approach to Understanding Radicalization, Global Change, Peace and Security 22(1), 38

49. Zahid, F. (2017). Radicalization of Campuses in Pakistan. Count. Terror. Trends Anal. 9, 12-15 